\title{
MYCOBIOTA IN THE SEEDS OF NARROW- LEAVED ASH (FRAXINUS ANGUSTIFOLIA VAHL)
}

\section{VRSTE GLJIVA U SJEMENU POLJSKOGA JASENA (Fraxinus angustifolia Vahl)}

\author{
Jelena KRANJEC ORLOVIĆ* , Ivan ANDRIĆ** , Ida BULOVEC*** , Danko DIMINIĆ*
}

\begin{abstract}
SUMMARY
Narrow-leaved ash (Fraxinus angustifolia), currently the most damaged forest tree species in the Republic of Croatia, is suffering from dieback primarily caused by pathogenic fungus Hymenoscyphus fraxineus. Since health status of seeds is very important for future seedling production, objective of this study was to screen narrow-leaved ash seeds for presence of this main pathogen and other potentially parasitic fungi. Seeds were collected from five locations and analysed using three different methods. Results revealed relatively good health status of inspected seeds, with total of 15 different fungal taxa identified in less than $40 \%$ of samples and no confirmation of Hymenoscyphus fraxineus presence. Most frequently detected fungi were various species of genus Alternaria and species Sphaerulina berberidis, while other taxa occurred rarely. Although identified fungal species haven't caused visible symptoms on seeds after one to two months of storage, many of them are known seed pathogens or opportunistic ash (Fraxinus spp.) pathogens and could have a negative effect on seeds after longer period of storage or storage in unfavourable conditions.
\end{abstract}

KEY WORDS: fungal isolation, nested PCR, Alternaria sp., Sphaerulina berberidis

\section{INTRODUCTION}

\section{UVOD}

Narrow-leaved ash (Fraxinus angustifolia Vahl), ecologically and economically very important species in lowland forests, is currently the most damaged forest tree species in the Republic of Croatia with $75 \%$ of trees having significantly defoliated crown according to the ICP Forests program data for 2017 (Potočić et al. 2018). Existing research revealed that, among other factors, there are several parasitic fungi involved in the decline in roots and stem collars of affected trees (Kranjec 2017), with pathogenic fungus Hymenoscyphusfraxineus (T. Kowalski) Baral, Queloz \& Hosoya con- firmed as the primary causative agent of crown dieback at multiple locations (Diminić 2015, Milotić et al. 2016). Presence of this pathogen responsible for large-scale dieback of common (Fraxinus excelsior L.) and narrow-leaved ash throughout Europe has been confirmed in roots, stems, branches, shoots, petioles and leaves of both tree species (Kowalski 2006, Gross et al. 2014, Chandelier et al. 2016), but also in the symptomatic and visually healthy seeds of common ash from Latvia and Sweden (Cleary et al. 2013, Hayatgheibi 2013, Marčiulynienè et al. 2018).

Yield and health status of narrow-leaved ash seeds are of great importance in the Republic of Croatia, since they are

\footnotetext{
* Dr. sc. Jelena Kranjec Orlović, jkranjec@sumfak.hr; prof. dr. sc. Danko Diminić, ddiminic@sumfak.hr, University of Zagreb, Faculty of Forestry, Department of Forest Protection and Wildlife Management, Svetošimunska 25, 10002 Zagreb, Republic of Croatia

* Dr. sc. Ivan Andrić, iandric@sumfak.hr, University of Zagreb, Faculty of Forestry, Department of Forest Genetics, Dendrology and Botany, Svetošimunska 25, 10002 Zagreb, Republic of Croatia

*** Ida Bulovec, univ. bacc. ing. silv., Bukovačka cesta 302a, 10000 Zagreb, Republic of Croatia
} 
necessary for nursery production of seedlings, majority of which are further used for forest stand regeneration or afforestation. For this purpose seeds are collected from adult trees in existing natural stands selected and registered as seed sources, forest stands which are phenotypically above average and specially managed for the purpose of seed collection and thus registered as seed stands and seed orchards established also for the purpose of seed collecting, from the genetically superior individual trees (Anon 2009, 2011, 2013, 2014).

Fungal presence in the seeds of forest tree species in general is considered to be a significant cause of shortened seed longevity during storage (Sutherland et al. 2002), reduced seed germination due to embryo or endosperm deterioration and potential cause of diseases that affect other developmental stages of plants, such as increased damping-off, shoot dieback, cankers and dieback of older seedlings (Cram 2009), although number of species just act as endophytes or saprotrophs and do not adversely affect the performance of seeds sown in nurseries (Mittal and Wang 1987).

In Croatian narrow-leaved ash forest stands there was a recorded case of seedlings delivered from a nursery $\mathrm{Za}$ lužje, Forestry Office (FO) Vinkovci, which expressed symptoms of Hymenoscyphus fraxineus dieback approximately one month after being planted in the field, FO Vinkovci, Management Unit (MU) Vrbanske šume, Subcompartment (SC) 91b, although the pathogen wasn't confirmed on older ash trees sampled in the area nearby SC 132a (MU Vrbanske šume) and SC 49a (MU Kusare) (FO Vinkovci) (Anon 2015). This finding raised a question of infection origin and possibility that pathogen spread from seeds into the plant tissue, eventually causing visible dieback symptoms in grown seedlings.

The objective of this research was to screen narrow-leaved ash seeds for the presence of pathogenic fungus Hymenoscyphus fraxineus and simultaneously detect other possible seed-borne pathogens in order to estimate the health status and suitability of seeds collected from registered seed sources and seed stands for further nursery seedling production.

\section{MATERIALS AND METHODS MATERIJALI I METODE}

Fraxinus angustifolia seeds were collected in period from August to November 2017 from visually healthy trees in four natural forest stands registered as narrow-leaved ash seed sources and one registered narrow-leaved ash seed stand (Table 1). Seeds were examined for fungal presence after one to two months of storage at room temperature, using both classical method of mycelia isolation on artificial media and a nested PCR method to analyse DNA directly from seeds. Seeds were additionally screened for presence of pathogenic fungus Hymenoscyphus fraxineus using species specific primers (Johansson et al. 2010).

\section{Isolation of fungi from seeds - Izolacija gljiva iz sjemena}

Twelve seeds from each of five locations were used for fungal isolation on malt extract agar medium (MEA, Oxoid, Basingstoke, UK) supplemented with streptomycin sulphate (200 $\mathrm{mg} \mathrm{l}^{-1}$, Sigma-Aldrich, St. Louis, USA). Seeds were surface sterilized in a solution of sodium hypochlorite (approx. $4 \%$ active chlorine) for one minute and then rinsed three times in sterile distilled water. Seeds cut in half were plated on medium in Petri dishes $\left(9 \mathrm{~cm}\right.$ diameter) and incubated in dark at $20^{\circ} \mathrm{C}$ for four weeks (Bulovec 2018). Petri dishes were checked weekly for fungal growth and emerging mycelia were subcultured to MEA medium. Pure cultures were grouped into morphotypes and at least one isolate of each morphotype group was used for molecular identification. Extraction of DNA was performed according to Allemann et al. (1999) with modifications (Kranjec et al. 2017) and PCR amplification was conducted with primers ITS 1 and ITS 4 (White et al. 1990) in $25 \mu$ reactions containing 200 $\mu \mathrm{M}$ deoxyribonucleoside triphosphates, $0.4 \mu \mathrm{M}$ of each primer, $0.5 \mathrm{U}$ of Taq DNA polymerase with reaction buffer (Sigma-Aldrich, St. Louis, USA), $1.5 \mathrm{mM} \mathrm{MgCl}_{2}$ and $1 \mu \mathrm{l}$ of 100 -fold diluted DNA template. Cycling conditions were as follows: an initial denaturation at $95^{\circ} \mathrm{C}$ for 5 min, 35 cycles of denaturation at $95^{\circ} \mathrm{C}$ for $30 \mathrm{~s}$, annealing at $50{ }^{\circ} \mathrm{C}$ for $45 \mathrm{~s}$, extension at $72{ }^{\circ} \mathrm{C}$ for $90 \mathrm{~s}$ and a final

Table 1. Locations and dates of narrow-leaved ash seed collection Tablica 1. Lokacije i datumi sakupljanja sjemena poljskoga jasena

$\begin{array}{lcc}\text { Forestry Office } & \text { Location } & \text { Dates of seed collection (year 2017) } \\ \text { Gunja } & \text { natural stand HR-FAN-SI-121/011 } & \text { 22 August }-6 \text { September } \\ \text { Lipovljani } & \text { seed stand HR-FAN-SS-123/160 } & 21 \text { August }-15 \text { September } \\ \text { Novoselec } & \text { natural stand HR-FAN-SI-123/366 } & 25 \text { August }-3 \text { November } \\ \text { Vukovar } & \text { natural stand HR-FAN-SI-111/030 } & 23 \text { August }-30 \text { August } \\ \text { Županja } & \text { natural stand HR-FAN-SI-121/305 } & 23 \text { August }-6 \text { September }\end{array}$


Table 2. Percentage of narrow-leaved ash seeds with detected fungal presence

Tablica 2. Udio sjemena poljskoga jasena u kojemu je utvrđena prisutnost gljiva

\begin{tabular}{lcc} 
Location & $\begin{array}{c}\text { Percentage of seeds with } \\
\text { fungal presence detected } \\
\text { using nested PCR approach } \\
\text { Ldio sjemena u kojem su } \\
\text { potvrđiene gljive korištenjem } \\
\text { nested PCR metode }\end{array}$ & $\begin{array}{c}\text { Percentage of seeds with } \\
\text { fungal presence detected by } \\
\text { isolation on MEA medium } \\
\text { Udio sjemena u kojem su } \\
\text { potvrđene gljive izolacijom } \\
\text { na MEA hranjivu podlogu }\end{array}$ \\
\hline Gunja & $35 \%$ & $50 \%$ \\
Lipovljani & $55 \%$ & $50 \%$ \\
Novoselec & $20 \%$ & $25 \%$ \\
Vukovar & $30 \%$ & $58 \%$ \\
Županja & $25 \%$ & $25 \%$
\end{tabular}

extension step at $72{ }^{\circ} \mathrm{C}$ for $5 \mathrm{~min}$. The resulting PCR products were sequenced using primer ITS 4 at the DNA sequencing facility of Macrogen Europe (Amsterdam, Netherlands). After processing raw data using the BioEdit Sequence Alignment Editor v.7.2.5 software (Hall 1999), sequences were identified by comparison with reference sequences in NCBI GenBank using BLAST tool (Altschul et al. 1990). Sequences with $98-100 \%$ similarity were identified to the species level and with $94-97 \%$ of similarity to the genus level (Bakys et al. 2011).

\section{Analysis of DNA from seeds - Analiza DNA iz sjemena}

Twenty seeds from each of five locations were analyzed for fungal presence using a nested PCR method. After surface disinfection of samaras by immersing them in 35\% $\mathrm{H}_{2} \mathrm{O}_{2}$ for three minutes, seeds were aseptically removed, cut into small pieces ( $1-2 \mathrm{~mm}$ long), placed in separate $2 \mathrm{ml}$ centrifuge tubes and freeze-dried for $24 \mathrm{~h}$ (Cleary et al. 2013). Samples were homogenized in TissueLyser II (Qiagen, Hilden, Germany) at $30 \mathrm{~Hz}$ for two minutes. DNA was extracted following the protocol according to Minas et al. (2011). First PCR was conducted using the primers ITS1-F (Gardes and Bruns 1993) and ITS 4 (White et al. 1990) under the same cycling conditions and with same reagents concentrations as in the described PCR protocol used for DNA analysis of isolated mycelia. The PCR products were size separated by gel electrophoresis on $2 \%$ agarose gels stained with GelStar Nucleic Acid Gel Stain (Lonza, Rockland, USA) and visualised under UV light. All bands were aseptically excised from the gel, purified using the Wizard SV Gel and PCR Clean-Up System (Promega, Madison, USA) and re-amplified in a second PCR using the primers ITS 1 and ITS 4 (White et al. 1990) under the same cycling conditions and with same reagents concentrations as in the first one. The resulting PCR products were sequenced using primer ITS 4 at the DNA se- quencing facility of Macrogen Europe (Amsterdam, Netherlands) and identified using NCBI GenBank database as already described in this paper.

\section{Detection of Hymenoscyphus fraxineus in seeds - Utvrđivanje prisutnosti gljive Hymenoscyphus fraxineus u sjemenu}

DNA extracted from seeds, as previously described, was additionally checked for the presence of Hymenoscyphus fraxineus in a PCR reaction with species specific primers: forward (5'AGCTGGGGAAACCTGACTG) and reverse (5'ACACCGCAAGGACCCTATC) (Johansson et al. 2010), and with same reagents concentrations as in previous analysis. The thermal cycling was carried out as follows: an initial denaturation step at $94^{\circ} \mathrm{C}$ for $5 \mathrm{~min}, 35$ cycles of denaturation at $94{ }^{\circ} \mathrm{C}$ for $30 \mathrm{~s}$, annealing at $62^{\circ} \mathrm{C}$ for $60 \mathrm{~s}$, extension at $72{ }^{\circ} \mathrm{C}$ for $30 \mathrm{~s}$ and a final extension step at 72 ${ }^{\circ} \mathrm{C}$ for 7 min (Hayatgheibi 2013). DNA of confirmed $H y$ menoscyphus fraxineus isolate obtained from earlier research (isolated from Fraxinus angustifolia stem collar, Kranjec 2017) was used as a positive control in each PCR reaction. PCR products were run on $1 \%$ agarose gels stained with GelStar Nucleic Acid Gel Stain (Lonza, Rockland, USA) and visualised under UV light.

\section{RESULTS}

REZULTATI

Analysis of Fraxinus angustifolia seeds by mycelia isolation on MEA medium and nested PCR revealed fungal presence in $20-58 \%$ of screened seeds, depending on the method used and location they originated from (Table 2). Isolation of mycelia on MEA medium resulted in growth of 26 fungal isolates belonging to 15 different taxa, 10 of which were identified to the species level (Table 3). The nested PCR analysis resulted in identification of 19 different fungal taxa, 10 of which were identified to the species level (Table 4).

Most frequently detected taxa were Sphaerulina berberidis and Alternaria sp. with Alternaria alternata and A. tenuissima identified to the species level. Among the most frequently detected were also seven sequences obtained in nested PCR which corresponded to Fungal endophyte isolate 4480 according to NCBI GenBank and might be a species of genus Sphaerulina, which is next closest match in the given database. Species of Alternaria occurred in the seeds from all five locations included in this research and Sphaerulina berberidis occurred in seeds from four of those locations (not confirmed only in seeds from stand HR-FANSI-111/030 in Vukovar).

Neither of sequences obtained by first two described methods belonged to Hymenoscyphus fraxineus. Presence of this pathogenic fungus in seeds was not confirmed by using 
Table 3. Identified fungal taxa in narrow-leaved ash seeds by mycelia isolation on MEA medium

Tablica 3. Taksoni gljiva identificirani u sjemenu poljskoga jasena izolacijom micelija na MEA hranjive podloge

\begin{tabular}{|c|c|c|}
\hline $\begin{array}{l}\text { Fungal taxa identified according } \\
\text { to NCBI GenBank } \\
\text { Identificirani takson gljive prema NCBI } \\
\text { GenBank bazi podataka }\end{array}$ & $\begin{array}{l}\text { Accession number in NCBI } \\
\text { GenBank } \\
\text { Identifikacijski broj sekvence } \\
\text { u NCBI GenBank bazi }\end{array}$ & $\begin{array}{l}\text { Percentage of Fraxinus angustifolia seeds } \\
\text { where fungus is present } \\
\text { Udio sjemena poljskoga jasena na kojem } \\
\text { je gljiva prisutna }\end{array}$ \\
\hline Alternaria sp. & MH137756 & $13,3 \%$ \\
\hline Alternaria tenuissima (Kunze) Wiltshire & $\begin{array}{l}\text { MH137745 } \\
\text { MH137746 }\end{array}$ & $3,3 \%$ \\
\hline Cercospora beticola Sacc. & MH137755 & $1,6 \%$ \\
\hline Cladosporium cladosporioides (Fresen.) G.A. de Vries & MH137753 & $1,6 \%$ \\
\hline Cladosporium herbarum (Pers.) Link & MH137759 & $1,6 \%$ \\
\hline Cladosporium sp. & MH137748 & $1,6 \%$ \\
\hline Colletotrichum sp. & MH137751 & $1,6 \%$ \\
\hline Phomopsis velata (Sacc.) Traverso & MH137754 & $1,6 \%$ \\
\hline Phomopsis cucurbitae McKeen 1957 & MH137752 & $1,6 \%$ \\
\hline Botryosphaeria stevensii Shoemaker & MH137758 & $1,6 \%$ \\
\hline Fusarium oxysporum Schltdl. & MH137749 & $1,6 \%$ \\
\hline Lophiostoma sp. & MH137750 & $1,6 \%$ \\
\hline Penicillium sp. & MH137760 & $1,6 \%$ \\
\hline Sphaerulina berberidis (Niessl) Quaedvl., Verkley \& Crous & MH137747 & $6,6 \%$ \\
\hline Venturia fraxini Aderh. & MH137761 & $1,6 \%$ \\
\hline
\end{tabular}

species specific primers for PCR amplification either, as there were no visible PCR products on agarose gels besides positive controls included in each reaction.

\section{DISCUSSION RASPRAVA}

With total of 15 different fungal taxa present in less than $40 \%$ of samples (in 58 out of 160 in total), narrow-leaved ash seeds revealed relatively good health status in comparison with common ash (Fraxinus excelsior) seeds analysed in similar European studies, where larger number of taxa were identified in smaller number of samples and with averagely higher individual presence frequency (Cleary et al. 2013, Hayatgheibi 2013).

Species of the most frequently detected genus in this research, Alternaria sp., haven't caused visible symptoms on seeds although the identified Alternaria alternata and Alternaria tenuissima are reported as seed pathogens on Betula spp. and Robinia pseudoacacia L. (Lilja 1979, Sunita 1998) and causative agents of Malus spp. and Punica granatum L. fruit rot during storage (Zambounis et al. 2015). Alternaria alternata has also been found in symptomatic bark, wood and buds of declining Fraxinus excelsior (Pukacki and Przybył 2005, Davydenko et al. 2013, Kowalski et al. 2016), indicating that it can act as an opportunistic pathogen in already declining ash tissue, possibly in the narrow-leaved ash seeds as well if they are under the influence of negative biotic and abiotic factors while on a tree or stored in unfavourable conditions after the harvest. Other frequently de- tected species, Sphaerulina berberidis, has so far been reported only as leaf endophyte of several tree species (Eo et al. 2014) and most probably has the same role in the narrowleaved ash seeds since it hasn't induced any visible symptoms in the analysed samples.

The remainder of identified species in narrow-leaved ash seeds were present in only one to three samples, but included some of the well known tree pathogens such as Phomopsis velata (synonym Diaporthe eres) and Botryosphaeria stevensii (synonym Diplodia mutila), which were also found in Fraxinus excelsior seeds in Latvia and Sweden (Cleary et al. 2013). Former is known for causing stem canker and dieback of several tree species (Quaroni et al. 1980, Anagnostakis 2007, Thomidis and Michailides 2009), fruit deterioration (Ristić et al. 2016) and being present in necrotic tissue and collar rots of Fraxinus excelsior (Kowalski et al. 2016, Langer 2017). Latter is known as a parasite involved in bark necrosis, canker formation and dieback of Fraxinus excelsior and Fraxinus ornus L., Quercus spp. and other tree species (Ragazzi et al. 1999, Przybył 2002, Sidoti and Granata 2004, Sims et al. 2016). Some of identified species are reported to be seed or fruit pathogens on other plant species, like Fusarium oxysporum on Robinia pseudoacacia seeds (Sunita 1999), Cladosporium cladosporioides on tobacco seeds (Nicotiana tabacum L.) (Wang et al. 2014) and stored hazelnuts (Corylus avellana L.) (Moghaddam and Taherzadeh 2007), and Cladosporium herbarum on stored figs (Ficus carica L.) (Montealegre et al. 2000) and Prunus spp. fruits (Tonini and Capriotti 1996). Venturia fraxini, known primarily as endophyte (Schlegel et al. 2016), but 
Table 4. Identified fungal taxa in narrow-leaved ash seeds by nested polymerase chain reaction (PCR)

Tablica 4. Taksoni gljiva identificirani u sjemenu poljskoga jasena u ugniježđenoj lančanoj reakciji polimerazom (PCR)

\begin{tabular}{|c|c|c|c|}
\hline $\begin{array}{l}\text { Closest sequence match } \\
\text { in NCBI GenBank } \\
\text { Sekvenca s najvećom podudarnošću } \\
\text { u NCBI GenBank bazi podataka }\end{array}$ & $\begin{array}{l}\text { Fungal taxa identified } \\
\text { Identificirani takson gljive }\end{array}$ & $\begin{array}{l}\text { Accession number } \\
\text { in NCBI GenBank } \\
\text { Identifikacijski broj } \\
\text { sekvence u NCBI } \\
\text { GenBank bazi }\end{array}$ & $\begin{array}{l}\text { Percentage of Fraxinus } \\
\text { angustifolia seeds where } \\
\text { fungus is present } \\
\text { Udio sjemena poljskoga jasena } \\
\text { na kojem je gljiva prisutna }\end{array}$ \\
\hline Alternaria alternata & Alternaria alternata (Fr.) Keissl. & $\begin{array}{l}\text { MH137762 } \\
\text { MH137763 } \\
\text { MH137764 } \\
\text { MH137765 }\end{array}$ & $4 \%$ \\
\hline Alternaria brassicicola/A. alternata & Alternaria sp. FA_N8V7 & $\begin{array}{l}\text { MH137766 } \\
\text { MH137767 }\end{array}$ & $2 \%$ \\
\hline Alternaria sp. isolate $\mathrm{B} 6-25$ & Alternaria sp. FA_L9 & MH137768 & $1 \%$ \\
\hline $\begin{array}{l}\text { Alternaria alternata/A. porri/A. gaisen/ } \\
\text { A. tenuissima/A. brassicae/A. mali/ } \\
\text { A. ochroleuca }\end{array}$ & Alternaria sp. FA_Z11 & MH137769 & $1 \%$ \\
\hline Alternaria sp./Phoma sp./Talaromyces sp. & Ascomycota sp. FA_L18 & MH137770 & $1 \%$ \\
\hline Aspergillus ruber & $\begin{array}{l}\text { Aspergillus ruber (Jos. König, Spieck. \& W. } \\
\text { Bremer) Thom \& Church }\end{array}$ & MH137771 & $1 \%$ \\
\hline Cladosporium sp. A144 & Cladosporium sp. FA_V9 & MH137772 & $1 \%$ \\
\hline Cladosporium cladosporioides & $\begin{array}{l}\text { Cladosporium cladosporioides (Fresen.) G.A. de } \\
\text { Vries }\end{array}$ & MH137773 & $1 \%$ \\
\hline Cladosporium herbarum & Cladosporium herbarum (Pers.) Link & MH137774 & $1 \%$ \\
\hline Cryptococcus tephrensis & $\begin{array}{l}\text { Vishniacozyma tephrensis Vishniac ex Xin Zhan } \\
\text { Liu, F.Y. Bai, M. Groenew. \& Boekhout }\end{array}$ & MH137775 & $1 \%$ \\
\hline Diaporthe eres & Phomopsis velata (Sacc.) Traverso & MH137776 & $1 \%$ \\
\hline Didymella heteroderae & $\begin{array}{l}\text { Didymella heteroderae (Sen Y. Chen, D.W. Dicks. } \\
\text { \& Kimbr.) Qian Chen \& L. Cai }\end{array}$ & MH137777 & $1 \%$ \\
\hline Diplodia mutila & Botryosphaeria stevensii Shoemaker & $\begin{array}{l}\text { MH137778 } \\
\text { MH137779 }\end{array}$ & $2 \%$ \\
\hline Mycosphaerella coacervata & Mycosphaerella coacervata Syd. & MH137780 & $1 \%$ \\
\hline Fungal endophyte isolate 4480 & Fungal endophyte FA_2017 & $\begin{array}{l}\text { MH137781 } \\
\text { MH137782 } \\
\text { MH137783 } \\
\text { MH137784 } \\
\text { MH137785 } \\
\text { MH137786 } \\
\text { MH137787 }\end{array}$ & $7 \%$ \\
\hline Uncultured Ascomycota isolate FL7.5 & Ascomycota sp. FA_Z19 & MH137788 & $1 \%$ \\
\hline Phoma sp. ZP-40 & Phoma sp. FA_G14 & MH137789 & $1 \%$ \\
\hline Phomopsis sp. RJ-2015 isolate 310Jb14 & Phomopsis sp. FA_N6 & MH137790 & $1 \%$ \\
\hline Sphaerulina berberidis & $\begin{array}{l}\text { Sphaerulina berberidis (Niessl) Quaedvl., Verkley } \\
\text { \& Crous }\end{array}$ & $\begin{array}{l}\text { MH137791 } \\
\text { MH137792 } \\
\text { MH137793 } \\
\text { MH137794 }\end{array}$ & $4 \%$ \\
\hline
\end{tabular}

also confirmed in leaf blotches and other necrotic tissue on Fraxinus spp. (Anselmi 2001, Bakys et al. 2009), is first time reported in ash seeds. For the rest of the identified species there is no documented evidence of their presence in trees. Instead they are known for being pathogens of agricultural plants (Cercospora beticola, Phomopsis cucurbitae) (Bertetti et al. 2012, Vaghefi et al. 2017), pathogens of stored Pisum sativum L. seeds (Aspergillus ruber) (Harman et al. 1972), saprotrophs in forest soil (Vishniacozyma tephrensis) (Mašínová et al. 2017), parasites of nematodes (Didymella heteroderae) (Chen et al. 1996) and leaf spot causing agents on Coprosma robusta Raoul (Mycosphaerella coacervata) (Hood 1985). Since most of the described species were present at low frequencies their effect on general health status of seeds cannot by very significant, but ability of those known as potential parasites to induce symptoms and decline of seeds and later seedlings under the unfavourable conditions remains possible.

Hymenoscyphus fraxineus was not found in the seeds of Fraxinus angustifolia analysed in this research performed 
by applied methodology, thus not supporting the hypothesis that fungus has spread from infected seeds to seedlings planted in the field from the local nursery. Still, these findings do not exclude the possibility that the fungus could be present and thus spread on the surface of samaras, since this aspect of transmission was not investigated. The fact that this pathogen has been confirmed in both symptomatic and visually healthy seeds from trees of various levels of susceptibility to the fungus in similar research conducted on Fraxinus excelsior (Cleary et al. 2013, Hayatgheibi 2013, Marčiulynienè et al. 2018) and not in the Fraxinus angustifolia seeds analysed in this research, could be due to high summer temperatures (July and August 2017 maximum > $35^{\circ} \mathrm{C}$ ) (DHMZ 2017b, a) characteristic for the narrow-leaved ash distribution area in the Republic of Croatia, which seems to be a limiting factor for the spread of pathogen (Hauptman et al. 2013, Grosdidier et al. 2018) or due to seed collection method, where only seeds from visually healthy narrow-leaved ash trees from registered seed stands and natural stands registered as seed sources are collected for further purpose of nursery seedling production. In addition, recent surveys conducted by Marčiulyniené et al. (2018) found no evidence of fungus being able to spread from infected seeds to grown plants, which still doesn't exclude this possibility in the opinion of authors.

\section{CONCLUSION ZAKLJUČAK}

Analysed narrow-leaved ash seeds collected from visually healthy trees from registered seed sources and seed stand revealed relatively low level fungal presence in comparison to other similar studies, indicating good health status and usability for further nursery seedling production regarding this particular aspect. Identified fungal species haven't caused visible symptoms on seeds after one to two months of storage, not excluding their possible negative effect on seeds after longer period of storage or storage in unfavourable conditions, since some of them are known as seed pathogens and some are reported as opportunistic parasites in necrotic tissues of Fraxinus spp. Presence of pathogenic fungus Hymenoscyphus fraxineus in seeds was not confirmed, so it can be concluded that potential dieback of seedlings caused by this pathogen in nurseries or in the field is a consequence of infections from affected narrow-leaved ash stands in the vicinity rather than spread of fungus from infected seeds.

\section{ACKNOWLEDGEMENT ZAHVALA}

This research was carried out with the financial support of the Croatian Science Foundation under the project „The role of biotic agents on vitality of narrow-leaved ash (Fraxinus angustifolia Vahl) in Croatian floodplain forests" FRAXINPRO (IP-11-2013). We thank Croatian Forests Ltd. for providing samples for this research and Mirjana Grahovac-Tremski for kindly providing all the necessary information regarding seed origin, collection and storage.

\section{REFERENCES}

\section{LITERATURA}

- Allemann C., P. Hoegger, U. Heiniger and D. Rigling, 1999: Genetic variation of Cryphonectria hypoviruses (CHV1) in Europe, assessed using restriction fragment length polymorphism (RFLP) markers, Molecular Ecology, 8 (5): 843-854.

- Altschul, S. F., W. Gish, W. Miller, E. W. Myers and D. J. Lipman, 1990: Basic local alignment search tool, Journal of Molecular Biology, 215 (3): 403-10.

- Anagnostakis, S. L., 2007: Diaporthe eres (Phomopsis oblonga) as a pathogen of butternut (Juglans cinerea) in Connecticut, Plant Disease, 91 (9): 1198-1198.

- Anon., 2009: Law on forest reproduction material (Zakon o šumskom reprodukcijskom materijalu). Narodne novine 75/2009, Zagreb, Croatia, 30 June 2009.

- Anon., 2011: Law on changes and amendments of law on forest reproduction material (Zakon o izmjenama i dopunama zakona o šumskom reprodukcijskom materijalu). Narodne novine 61/2011, Zagreb, Croatia, 3 June 2011.

- Anon., 2013: Law on changes and amendments of law on forest reproduction material (Zakon o izmjenama i dopunama zakona o šumskom reprodukcijskom materijalu). Narodne novine 56/2013, Zagreb, Croatia, 10 May 2013.

- Anon., 2014: Law on change of law on forest reproduction material (Zakon o izmjeni zakona o šumskom reprodukcijskom materijalu). Narodne novine 14/2014, Zagreb, Croatia, 5 February 2014

- Anon., 2015: Project The role of biotic agents on vitality of narrow-leafed ash (Fraxinus angustifolia Vahl.) in Croatian floodplain forests report for period from June 13th 2014 to June 12th 2015, University of Zagreb, Faculty of Forestry.

- Anselmi, N., 2001: Main diseases of high quality timber broadleaves, Annali-Accademia Italiana di Scienze Forestali: 79-99.

- Bakys, R., A. Vasiliauskas, K. Ihrmark, J. Stenlid, A. Menkis and R. Vasaitis, 2011: Root rot, associated fungi and their impact on health condition of declining Fraxinus excelsior stands in Lithuania, Scandinavian Journal of Forest Research, 26 (2): 128-135.

- Bakys, R., R. Vasaitis, P. Barklund, K. Ihrmark and J. Stenlid, 2009: Investigations concerning the role of Chalara fraxinea in declining Fraxinus excelsior, Plant Pathology, 58: 284-292.

- Bertetti, D., M. T. Amatulli, J. Cardinale, M. L. Gullino and A. Garibaldi, 2012: Phomopsis cucurbitae and Lasiodiplodia theobromae, new pathogens of melons and avocados marketed in Italy, Protezione delle Colture, (2): 29-29.

- Bulovec, I., 2018: Gljive i štetnici sjemena poljskoga jasena (Fraxinus angustifolia Vahl), Diplomski rad, Sveučilište u Zagrebu Šumarski fakultet.

- Chandelier, A., F. Gerarts, G. San Martin, M. Herman and L. Delahaye, 2016: Temporal evolution of collar lesions associated 
with ash dieback and the occurrence of Armillaria in Belgian forests, Forest Pathology, 46 (4): 289-297.

- Chen, S. Y., D. W. Dickson and J. W. Kimbrough, 1996: Phoma heteroderae sp. nov. isolated from eggs of Heterodera glycines, Mycologia, 88 (6): 885-891.

- Cleary, M. R., N. Arhipova, T. Gaitnieks, J. Stenlid and R. Vasaitis, 2013: Natural infection of Fraxinus excelsior seeds by Chalara fraxinea, Forest Pathology, 43 (1): 83-85.

- Cram, M. M., 2009: Seed Diseases and Seedborne Pathogens of North America, Tree planters' notes, 53 (2): 35-44.

- Davydenko, K., R. Vasaitis, J. Stenlid and A. Menkis, 2013: Fungi in foliage and shoots of Fraxinus excelsior in eastern Ukraine: a first report on Hymenoscyphus pseudoalbidus, Forest Pathology, 43 (6): 462-467.

- Diminić, D., 2015: Nova bolest jasena (Fraxinus spp.) u Hrvatskoj, In: S. Matić, F. Tomić and I. Anić (ed), Proizvodnja hrane i šumarstvo - temelj razvoja istočne Hrvatske, Hrvatska akademija znanosti i umjetnosti (HAZU), 363-373.

- Eo, J. K., B. H. Lee and A. H. Eom, 2014: Four Species of Endophytic Fungi Isolated from Leaves of Woody Plants in Mt. Hambaek, The Korean Journal of Mycology, 42 (3): 239-242.

- Gardes, M., T. D. Bruns, 1993: ITS primers with enhanced specificity for basidiomycetes-application to the identification of mycorrhizae and rusts, Molecular ecology, 2 (2): 113-118.

- Grosdidier, M., R. Ioos and B. Marçais, 2018: Do higher summer temperatures restrict the dissemination of Hymenoscyphus fraxineus in France?, Forest Pathology, e12426: 1-8.

- Gross, A., O. Holdenrieder, M. Pautasso, V. Queloz and T. N. Sieber, 2014: Hymenoscyphus pseudoalbidus, the causal agent of European ash dieback, Molecular Plant Pathology, 15 (1): 5-21.

- Hall, T. A., 1999: BioEdit: a user-friendly biological sequence alignment editor and analysis program for Windows 95/98/NT, Nucleic Acids Symposium Series, 41: 95-98.

- Harman, G. E., A. L. Granett and G. Nash, 1972: Seed deterioration by storage fungi, New York's Food and Life Sciences Quarterly, 5 (2): 19-22.

- Hauptman, T., B. Piškur, M. Groot, N. Ogris, M. Ferlan, D. Jurc and O. Holdenrieder, 2013: Temperature effect on Chalara fraxinea: heat treatment of saplings as a possible disease control method, Forest Pathology, 43 (5): 360-370.

- Hayatgheibi, H., 2013: Studies on the microflora associated with the seeds of European ash (Fraxinus excelsior) and the infection biology of the pathogen Hymenoscyphus pseudoalbidus causing ash dieback, Master Thesis, Swedish University of Agriculture Sciences, Faculty of Natural Resources and Agricultural Science.

- Hood, I. A., 1985: Algal and fungal leaf spots of native plants, Forest Pathology in New Zealand, Forest Research Institute, New Zealand, (12): 8-8.

- Johansson, S. B. K., R. Vasaitis, K. Ihrmark, P. Barklund and J. Stenlid, 2010: Detection of Chalara fraxinea from tissue of Fraxinus excelsior using species-specific ITS primers, Forest Pathology, 40 (2): 111-115.

- Kowalski, T., 2006: Chalara fraxinea sp. nov. associated with dieback of ash (Fraxinus excelsior) in Poland, Forest Pathology, 36 (4): 264-270.

- Kowalski, T., W. Kraj and B. Bednarz, 2016: Fungi on stems and twigs in initial and advanced stages of dieback of European ash (Fraxinus excelsior) in Poland, European Journal of Forest Research, 135 (3): 565-579.
- Kranjec, J., 2017: Uloga gljiva i gljivama sličnih organizama u odumiranju poljskoga jasena (Fraxinus angustifolia Vahl) u posavskim nizinskim šumama u Republici Hrvatskoj, University of Zagreb, Faculty of Forestry.

- Kranjec, J., M. Milotić, M. Hegol and D. Diminić, 2017: Gljivama slični organizmi u tlu odumirućih sastojina poljskog jasena (Fraxinus angustifolia Vahl), Šumarski List, (3-4): 115-122.

- Langer, G., 2017: Collar rots in forests of Northwest Germany affected by ash dieback, Baltic Forestry, 23 (1): 4-19.

- Marčiulyniene, D., K. Davydenko, J. Stenlid, D. Shabunin and M. Cleary, 2018: Fraxinus excelsior seed is not a probable introduction pathway for Hymenoscyphus fraxineus, Forest Pathology, 48 (1): 1-3.

- Mašínová, T., B. D. Bahnmann, T. Větrovský, M. Tomšovský, K. Merunková and P. Baldrian, 2017: Drivers of yeast community composition in the litter and soil of a temperate forest, FEMS Microbiology Ecology, 93 (2): fiw223-fiw223.

- Milotić, M., J. Kranjec and D. Diminić, 2016: Current status of ash dieback disease Hymenoscyphus fraxineus in Croatia, In: (ed), Natural resources, green technology \& sustainable development - GREEN/2, 124-124.

- Minas, K., N. R. McEwan, C. J. Newbold and K. P. Scott, 2011: Optimization of a high-throughput CTAB-based protocol for the extraction of qPCR-grade DNA from rumen fluid, plant and bacterial pure cultures, FEMS microbiology letters, 325 (2): 162169.

- Mittal, R., B. Wang, 1987: Fungi associated with seeds of eastern white pine and white spruce during cone processing and seed extraction, Canadian Journal of Forest Research, 17 (9): 10261034.

- Montealegre, J., J. Oyarzún, R. Herrera, H. Berger and L. Galletti, 2000: Fungi producing postharvest decay on brevas and fig fruits, Boletín de Sanidad Vegetal, Plagas, 26 (3): 439-443.

- Przybył, K., 2002: Fungi associated with necrotic apical parts of Fraxinus excelsior shoots, Forest Pathology, 32 (6): 387-394.

- Pukacki, P. M., K. Przybył, 2005: Frost Injury as a Possible Inciting Factor in Bud and Shoot Necroses of Fraxinus excelsior L, Journal of Phytopathology, 153 (9): 512-516.

- Quaroni, S., P. Sardi and R. Locci, 1980: Apical diebacks in Acer pseudoplatanus associated with Diaporthe eres Nits. (Phomopsis acerina Pir. \& Car.), Rivista di Patologia Vegetale, IV, 16 (3/4): 109-115.

- Ragazzi, A., S. Moricca and I. Dellavalle, 1999: Water stress and the development of cankers by Diplodia mutila on Quercus robur, Journal of Phytopathology, 147 (7/8): 425-428.

- Ristić, D., M. Stevanović, S. Stošić, I. Vučurović, K. Gašić, V. Gavrilović and S. Zivković, 2016: Diaporthe eres as a pathogen of quince fruit (Cidonia oblonga) in Serbia, In: D. Kovačević (ed), VII International Scientific Agriculture Symposium, "Agrosym 2016", 6-9 October 2016, Jahorina, Bosnia and Herzegovina. Proceedings, University of East Sarajevo, Faculty of Agriculture, 1270-1275.

- Schlegel, M., V. Dubach, L. v. Buol and T. N. Sieber, 2016: Effects of endophytic fungi on the ash dieback pathogen, FEMS Microbiology Ecology, 92 (9): 142-142.

- Sidoti, A., G. Granata, 2004: Manna ash (Fraxinus ornus): a new host of Diplodia mutila, Informatore Fitopatologico, 54 (2): 4951 . 
- Sims, L., D. Schmidt, M. Garbelotto, M. Uhler and J. Dahl, 2016: First report of bristlecone fir branch canker in California caused by Diplodia mutila, Plant Disease, 100 (12): 2534-2534.

- Sunita, S., 1998: Seed mycoflora of Robinia pseudoacacia Linn. and its control, Indian Forester, 124 (5): 347-350.

- Sunita, S., 1999: Evaluation of Robinia pseudoacacia Linn. seeds against fusarial wilt, Indian Journal of Forestry, 22 (1/2): 70-72.

- Sutherland, J. R., M. Diekmann and P. Berjak, 2002: Forest tree seed health for germplasm conservation, IPGRI.

- Thomidis, T., T. J. Michailides, 2009: Studies on Diaporthe eres as a new pathogen of peach trees in Greece, Plant Disease, 93 (12): 1293-1297.

- Tonini, G., M. Capriotti, 1996: Postharvest damage to stone fruits and its prevention, Informatore Agrario Supplemento, 52 (15): 32-45.
- Vaghefi, N., S. C. Nelson, J. R. Kikkert and S. J. Pethybridge, 2017: Genetic structure of Cercospora beticola populations on Beta vulgaris in New York and Hawaii, Scientific Reports, 7: 1726.

- Wang, H. C., J. Wang, W. H. Li, Y. F. Huang, H. Q. Xia, M. S. Wang, N. Lu, Y. S. Guo and C. Q. Zhang, 2014: Cladosporium cladosporioides identified in China on tobacco seeds, Plant Disease, 98 (7): 1002-1002.

- White, T. J., T. Bruns, S. Lee and J. W. Taylor, 1990: Amplification and direct sequencing of fungal ribosomal RNA genes for phylogenetics, PCR protocols: A Guide to Methods and Applications, Academic Press Inc., 315-322.

- Zambounis, A., A. Xanthopoulou, G. Karaoglanidis, A. Tsaftaris and P. Madesis, 2015: A new accurate genotyping HRM method for Alternaria species related to fruit rot diseases of apple and pomegranate, International Journal of Phytopathology, 4 (3): 159-165.

\section{SAŽETAK}

Poljski jasen (Fraxinus angustifolia Vahl) je u Republici Hrvatskoj trenutno najoštećenija šumska vrsta drveća, sa 75 \% stabala značajno osute krošnje prema podacima međunarodnog programa ICP Forests iz 2017. godine. Dosadašnja su istraživanja potvrdila patogenu gljivu Hymenoscyphus fraxineus kao primarnog uzročnika odumiranja krošanja poljskoga jasena na više lokacija te utvrdila njenu prisutnost u listovima, izbojcima, granama, bazi debla te korijenu stabala. Cilj ovog istraživanja bio je ispitati prisutnost navedenog patogena u sjemenu poljskoga jasena, a također i identificirati ostale vrste potencijalno parazitskih gljiva, kako bi se s navedenog aspekta moglo procijeniti zdravstveno stanje i uporabljivost sjemena u rasadničkoj proizvodnji poljskoga jasena za obnovu sastojina i pošumljavanje. Sjeme je prikupljeno na pet lokacija u sastojinama kategoriziranim kao sjemenski izvor ili sjemenska sastojina na području šumarija Novoselec, Lipovljani, Gunja, Županja i Vukovar. Za analizu sjemena skladištenog jedan do dva mjeseca korištene su tri različite metode, uključujući klasičnu metodu izolacije gljiva iz tkiva na hranjive podloge te molekularne metode izolacije ukupne stanične DNK iz sjemena i umnažanja ciljanih sekvenci u lančanoj reakciji polimerazom korištenjem univerzalnih početnica (ITS 1, ITS 1 - F, ITS 4) i početnica specifičnih za gljivu Hymenoscyphus fraxineus.

Analizom je utvrđeno ukupno 15 različitih taksona gljiva u manje od $40 \%$ ispitivanog sjemena, ukazujući na njegovo relativno dobro zdravstveno stanje. Najčešće su identificirani pripadnici roda Alternaria, od kojih su A. alternata i A. tenuissima identificirane do razine vrste, te vrsta Sphaerulina berberidis. Ostali identificirani taksoni zabilježeni su na svega jednoj do tri sjemenke. Iako utvrđeni taksoni gljiva nisu uzrokovali vidljive simptome ili propadanje sjemena nakon jednog do dva mjeseca skladištenja, velik broj njih se u literaturi navode kao patogeni sjemena i plodova različitih vrsta drveća, a dio i kao oportunistički paraziti prisutni u nekrotičnom tkivu jasena (Fraxinus spp.), zbog čega se ne može u potpunosti isključiti njihov negativan utjecaj na sjeme tijekom duljih perioda skladištenja ili izlaganja nepovoljnim uvjetima. Vrsta Hymenoscyphus fraxineus niti jednom korištenom metodom nije utvrđena u analiziranom sjemenu, te nije dokazana mogućnost njena širenja na uzgojene sadnice ovim putem. Time nije isključena mogućnost njene prisutnosti na površini plodova, tj. perutki, koje su u ovom istraživanju površinski sterilizirane kako bi se smanjio utjecaj uobičajeno prisutnih epifitnih gljiva na rezultate.

KLJUČNE RIJEČI: izolacija gljiva, ugniježđeni PCR, Alternaria sp., Sphaerulina berberidis 